
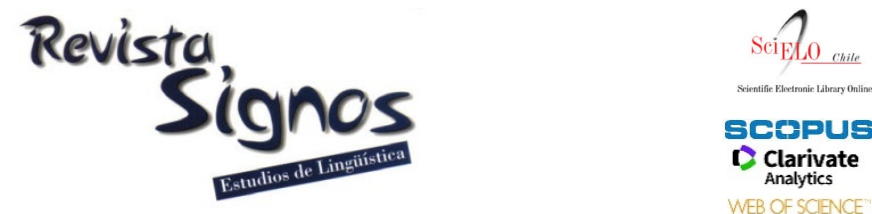

WEB OF SCIENCE

\title{
Constructing discourse: An experimental approach
}

\section{La construcción del discurso: Una aproximación experimental}

\author{
Inés Recio Fernández \\ HEIDELBERG UNIVERSITY \\ GERMANY \\ ines.recio@hcla.uni-heidelberg.de
}

\author{
Óscar Loureda \\ HEIDELBERG UNIVERSITY \\ GERMANY \\ oscar.loureda@uni-heidelberg.de
}

\author{
Ted J. M. Sanders \\ UTRECHT UNIVERSITY \\ THE NETHERLANDS \\ t.j.m.sanders@uu.nl
}

Received: 21-VI-2021 / Accepted: 25-X-2021

DOI: $10.4067 /$ S0718-09342021000301004

\begin{abstract}
This contribution aims at offering a state of the art about experimental research on mechanisms for referential and relational coherence, pivotal for the construction of discourse in the interlocutors' aim to recover of a relevant assumption in communication. The construction of discourse is a cognitive 'activity' that consists in decoding linguistic material of utterances and performing a series of mental operations to recover a relevant interpretation in a communicative exchange. For that purpose, interlocutors put to use linguistic mechanisms directed at establishing 'referential coherence' and 'relational coherence' to achieve discourse 'connectedness'. The cognitive effects of these mechanisms in terms of their consequences for discourse processing and interpretation can be approached by means of experimentation. Doing so allows the researcher to enrich scientific findings as provided by linguistic description and observational studies, helps refining theories of human verbal communication and comes along with a strong transfer potential for applied endeavors.
\end{abstract}

Key Words: Referential coherence, relational coherence, discourse marking, cognitive effort, experimentation.

\section{Resumen}

Esta contribución ofrece un estado de la cuestión acerca de la investigación experimental sobre los mecanismos de coherencia referencial y relacional, fundamentales para la construcción del discurso y para la recuperación de un supuesto relevante durante la comunicación. La construcción del discurso es una actividad cognitiva que consiste en descodificar el material lingüístico de los enunciados y en llevar a cabo una serie de operaciones mentales para recuperar una interpretación relevante en un intercambio comunicativo. Para ello los interlocutores ponen en marcha mecanismos lingüísticos dirigidos a establecer la coherencia referencial y la coherencia relacional y, para conectar el discurso. Los efectos cognitivos de estos mecanismos -sus consecuencias para el 
procesamiento y la interpretación del discurso- se pueden abordar a través de la experimentación. La aproximación experimental permite al investigador enriquecer hallazgos científicos derivados de estudios descriptivos y de la observación, contribuye a matizar teorías sobre el funcionamiento de la comunicación verbal humana y tiene un fuerte potencial de transferencia para fines aplicados.

Palabras Clave: Coherencia referencial, coherencia relacional, marcación discursiva, esfuerzo cognitivo, experimentación.

\section{INTRODUCTION}

The construction of discourse is an essentially cognitive process: interlocutors (re)create a relevant mental representation of what has been communicated by decoding the linguistic material provided by the interlocutor and performing mental computations to connect it to the given context (Graesser, Singer \& Trabasso, 1994; Sperber \& Wilson, 1995[1986]). These computations are called 'inferences', and consist in mental processes by which an interlocutor builds up a hypothesis of what has been linguistically conveyed, and enriches it by adjusting it to a particular context. Inferencing implies 'integration' processes which convey connectedness to the discourse (Givón, 2005; Sanders \& Spooren, 2007). These processes can be linked to different mechanisms that contribute to the 'connectedness' of discourse by establishing 'referential' and 'relational coherence', which are in turn related to more local or more global interpretative processes.

Lexical and grammatical mechanisms of 'referential coherence' shape discourse connectedness by resuming and pointing to an element a previously or subsequently given in the utterance. They are "the most evident elements that contribute to discourse coherence at a micro-linguistic level” (Ribera, Marín \& Alturo, 2018: 15). Mechanisms for referential coherence can be referring expressions and encapsulation mechanisms. Key to the distinction between both is that encapsulation implies "at least one predicate compressed in the phoric phrase" (González Ruiz \& Izquierdo Alegría, 2020: 752). Additionally, referring expressions 'reactivate' a specific entity as discourse representation progresses during processing, while encapsulation resumes discourse segment as a unity that results in a 'new' discourse entity (López Samaniego, 2015).

Referring expressions, like pronouns, zero anaphora or textual deixis, link discursive entities semantically and syntactically (Ribera et al., 2018; Gundel \& Abbott, 2019). In (1), the personal pronoun 'they" points to and resumes the subject ("Frank and Lina") of the previous segment, thereby conveying cohesion to the utterance and contributing to thematic progression.

(1) Frank and Lina are going to the Atacama desert in May. They have always wanted to visit Chile. 
Encapsulation mechanisms resume and compress discursive segments of predicative nature (González Ruiz \& Izquierdo Alegría, 2020) triggering inferential processes for the interlocutor to confirm, modify or add new information to a previously derived mental assumption and progress in discourse (Sinclair, 1993; Conte, 1996; Borreguero, 2018, among others). In (2):

(2) The politician announced new anti-pollution measures just before the summer vacation. This strategy brought him additional votes in the fall elections,

the nominal encapsulation phrase "this strategy" compresses the content of the predicate of the first utterance, labelling the encapsulated content as a new discourse entity (Francis, 1994; González Ruiz \& Izquierdo Alegría, 2020), and acts as a frame for the interpretation of its host segment ("brought him additional votes in the fall elections", López Samaniego, 2014).

Lexical mechanisms contributing to the 'relational coherence 'of discourses (Givón, 2005) at the semantic-discursive level encompass linguistic expressions like discourse markers (e.g. 'even', 'furthermore', 'therefore', 'however'...). Discourse markers instruct interlocutors on how to combine mental representations recovered from the utterance segments and the activated context to build a relevant assumption (Portolés, 2001[1998]; Sanders \& Spooren, 2007; Loureda, Cruz Rubio, Recio Fernández \& Rudka, 2021). In (3) the focus operator "even" conditions how the contrastive focus, "buffalos", is to be processed in relation to the alternatives of the utterance, "dogs, horses". Its role as a conventionalized processing instruction immediately conveys the focus the status of new contrastive information with the highest communicative value within the accessible context (Rooth, 1985, 1996; König, 1991; for experimental evidence and further references see also Cruz Rubio \& Loureda, 2019; Cruz Rubio, 2020; Loureda et al., 2021):

(3) Arthur owns a huge large amount of land. There, he keeps dogs, horses and even buffalos.

In a similar vein, the connective "therefore" in (4) conventionally establishes a specific discursive link between the mental representations activated from the utterance segments. It provides the interlocutor with an optimal frame for the interpretation of its host segment, which implies processing it as a reasoned consequence:

(4) It is over 40 degrees outside. Therefore, they will stay home.

One scientific challenge of approaching communication as a cognitive process is finding powerful explanations of how interlocutors manage the interaction between the linguistic and contextual features just set out that contribute to the construction of discourse and, as a result, how they (re)construct the meaning of discourses. The 
interaction between linguistic and contextual material can be described on the basis of a researcher's intuition or "educated guesses" (Noveck \& Sperber, 2007: 185), or on the basis of 'observable data,' as provided by empirical approaches to the study of discourse (Loureda, Recio Fernández, Cruz Rubio \& Nadal Fernández, 2019). Empirical approaches enrich intuition-based descriptions and can help overcome some of their limitations by providing data-based evidence to formulate, reconsider or further refine theories of human communication (Noveck, 2018).

Discourses can be dealt with from a rather external perspective, as a 'product' of communication. In those cases, empirical research often resorts to the tenets and methods of corpus linguistics. Corpus-based approaches enjoy a long tradition in discourse studies and have experienced a substantial impulse particularly since the 1990s, along with technical progress and the advancement of computer science (Zufferey, 2020). As concerns the internal perspective, which focuses on discourse as an 'activity', it implies approaching the mental processes involved in the construction of discourses and is thus usually performed by means of experimentation. Experimental methods and assumptions allow to investigate communicative phenomena as true cognitive processes, since they provide insight into observable behaviors connected to mental processes (Sandra, 2009; Cabedo Nebot \& Recio Fernández, 2021) by linking a specific reaction (e.g. an increased processing effort) to a specific stimulus (e.g. a particular utterance type).

Corpus and experimental studies are not mutually exclusive. Instead, combining both methodologies can provide the discourse researcher with 'converging evidence' from different perspectives, thus conferring enhanced robustness and reliability to empirically obtained results. Methodological triangulation by means of corpus and experimental approaches can also lead to 'diverging results' and lead to theoretical and descriptive readjustments (Sanders \& Evers-Vermeul, 2019; Loureda et al., 2019).

The basic assumption underlying the investigation of discourses from the 'discourseas-an-activity" perspective is that "cognitive processes need time, and complex processes require more time than simpler ones" (Dietrich, 2002: 17). During discourse processing and comprehension, interlocutors consider a given piece of information as worth processing under the assumption that the cognitive effort they invest to do so will be efficient, that is, balanced in terms of the "degree of achievement and expenditure" (Sperber \& Wilson, 1995[1986]). This underscores the fact that humans behave as "efficient information-processing devices" (Sperber \& Wilson, 1995[1986]: 46): a new piece of information — or bits of it - is processed and combined with entertained assumptions and/or with representations derived from previous linguistic material in search for the strongest 'contextual effects'.

In what follows, we describe some methodological issues for an experimental approach to the study of discourses, to then focus on key experimental research findings 
on phenomena of referential and relational coherence, essential for the (re)construction of discourse and, thus, for the recovery of relevance in communication.

\section{Experimental methods}

Observing how discourse features influence the creation and combination of mental representations to recover a coherent and relevant whole can be pursued by means of 'experimentation'. Experimentation in the realm of language studies resorts to methods rooting in the field of psychology, but has experienced a gradual increase of its autonomy by further developing a conceptual and methodological apparatus of its own that supplies data on the mental processes occurring in communicative exchanges specifically linked to theories of linguistic communication. Experimental language studies are essentially interdisciplinary: its concepts, methods and aims tie in with those of other disciplines. Besides psychological sciences, experimental linguistics finds spaces of intersection with sociology, computer sciences, artificial intelligence, biology or neurosciences.

Many techniques are available for experimental research. Depending on the extent to which a given experimental technique can access mental and neuronal activity, experimental methods can be classified in 'offline' and 'online' methods (Mertins, 2016). Research on processing during communication has resorted to all three (e.g. Noveck, 2018; Conklin, Pellicer-Sánchez \& Carrol, 2018; Gillioz \& Zufferey, 2021, and references therein). The decision to opt for one or another method depends on the researcher's study aims and, more specifically, on whether the data output provided by a given method is a good indicator of the processes actually involved in the communicative task under study:

'Offline methods' reflect conscious decision-making or explicit knowledge by the participants. The tasks they consist of are usually designed to be solved with a time delay (e.g. untimed questionnaires or acceptability judgments), so they do not provide direct access to mental processes. The output of offline explicit tasks can be affected by participants' subjectivity, since they depend on conscious reflections. Offline methods can also involve implicit decision making, where the researcher simply observes the participants behavior when confronted with a discursive stimulus in a so-called 'action task', which does not require them to supply a reflected answer (Gillioz \& Zufferey, 2021).

'Online methods' tap onto processes that are "more automatized and unconscious" (Mertins, 2016: 16). Some online experimental paradigms are chronometric and involve tasks that are often solved with a short time delay, thus providing mediated access to the mental processes involved in a given discourse task. Among these tasks are eyetracking studies, which have developed notably in language research particularly during the last two decades. In a discourse study with eye-tracking, the participant's gaze is tracked and timed while he is performing a discourse-related task, like reading a text on 
a computer screen. Due to their higher complexity or cognitive prominence, certain discursive features can influence the cognitive demands to solve a given task and thus the time needed for it and the resulting gaze-related processing patterns (Rayner, 2009; Conklin et al., 2018). Other online methods are neuro-imagine techniques, like EEG or magnetoencephalography. These techniques tap onto immediate mental processes by capturing and quantifying variations in brain activity. They thus give account of "highly automatized and unconscious mental and neuronal processes" (Mertins, 2016: 16).

Experimental research presupposes a high degree of control by the researcher over the different components of the experiment. This control concerns the materials provided to the participants for data collection, the selected experimental technique, the statistical methods chosen for data evaluation, and the participant samples (Cabedo Nebot \& Recio Fernández, 2020). It aims at ensuring the scientific rigor needed in an experimental setting by reducing to a maximum any potential influence on the results of factors others than the isolated variables at issue. Considering the statistical power ${ }^{2}$ at the stage of experimental design is an increasingly common practice in experimental linguistics. Further requirements of experimental research concern, firstly, preventing participants from becoming aware of the purpose of the study, which is achieved in particular by means of careful experimental design and implementation; secondly, leading to results that are generalizable to the population, which is achieved by collecting a sufficient amount of data, by performing an adequate statistical treatment and by ensuring the homogeneity of the participants sample (Sandra, 2009; Keating \& Jegerski, 2015; Loureda et al., 2021).

\section{Discourse features and communication processing}

Approaching linguistic communication from an experimental perspective can be done to deal with any phenomenon related to the construction of discourse. Earlier experimental investigations in the field of language studies share a common aim: empirically testing and validating different theories of communication (Noveck \& Sperber, 2007; Noveck, 2018 and references therein), and focus rather on language processing than on language production (Noveck, 2018; cf. also Gillioz \& Zufferey, 2021). Production studies have often been devoted to gathering empirical evidence to provide cognitive explanations for tendencies detected in the use of a specific mechanism by language users.

As concerns processing studies, a great deal of experimental research endeavors have been directed at studying how mechanisms central for the construction of discourses affect the recovery of a relevant mental representation of communication. As set out above, these mechanisms consist of linguistic expressions contributing to 'referential' or 'relational' discourse coherence (Givón, 2005; Sanders \& Spooren, 2001, 2007). The former are linguistic elements encoding instructions for interlocutors on how to saturate 
discourses informatively, thereby enhancing cohesion and contributing to the thematic progression of the communicative output. Mechanisms acting at the level of referential coherence are, for instance, pronouns or anaphoric expressions (see 3.1.). The latter correspond to linguistic expressions operating at a more global level that instruct interlocutors on how to connect and combine mental representations recovered from the linguistic input of segments of discourses and the context. These are, for instance, discourse connectives (see 3.2.).

Within these frames, many studies have set their focus on whether and how the use of referential or relational coherence mechanisms affect the strategies or mental operations applied by interlocutors during utterance interpretation. These operations can be related to global effects of the relational or referring mechanism under study, which concern the recovery of a mental assumption as a whole; or to more local effects, which explain how particular discourse segments are recovered within the frame given by the relational or referring expression, at a micro-structural level.

\subsection{Referential coherence and discourse processing}

'Referential coherence' refers to the phenomenon by which, during any task aimed at utterance interpretation, interlocutors informatively saturate certain discourse elements linking them to others to which they refer or whose information they compress (Sanders \& Spooren, 2007; Cuenca, 2010; López Samaniego, 2014, 2018). Referential coherence encompasses referring expressions and encapsulation mechanisms (see 1.). These contribute to discourse cohesion and to the thematic progression of communication (Borreguero, 2018), and can also function as guides for discourse comprehension (Sinclair, 1993; Schmolz, 2015; Parodi \& Burdiles, 2016; López Samaniego, 2014). For instance, in (5)

(5) Carol was decided to leave everything to be a volunteer. For her family it was not easy to accept such a noble reason to do so.

The lexical encapsulator "a noble reason" compresses the predicate of the first utterance, while also guiding how such predicate must be understood: firstly, by categorizing or labelling it as a reason; secondly, by even conveying the speaker's evaluation of Carol's actions (López Samaniego, 2018; González Ruiz \& Izquierdo Alegría, 2020).

Most experimental research in this area has been devoted to cognitive considerations concerning the resolution and the use of referring expressions, while encapsulation mechanisms have been approached so far empirically only in corpus analyses (López Samaniego, 2014, 2018; González Ruiz \& Izquierdo Alegría, 2020, and references therein).

From the perspective of information recovery during communication as an interplay between cognitive effort and cognitive benefits (Sperber \& Wilson, 1995[1986]), the 
mechanisms for referential coherence employed in a given discourse are good indicators of the degree of accessibility of a specific piece of information during processing (Ariel, 2001; Sanders \& Gernsbacher, 2004), whereby 'accessibility' can be operationalized as either the amount of referents available in the discourse, their distance to the referring expression, or their informative salience. In general, experimental evidence has demonstrated that the more accessible information is to a hearer, the less effortful it is to recover it (cf. e.g. Gernsbacher, 1990; Garrod \& Sanford, 1994; Sanders \& Gernsbacher, 2004; Fukumura \& van Gompel, 2012; Çokal, Sturt \& Ferreira, 2018).

Not only processing, but also the use of referring expressions seems to be constrained by cognitive considerations (in a sort of "form-function correlation", Ariel, 2001: 31). Specifically, the degree of activation of a piece of information in the speaker's mind influences how much and which type of linguistic material, i.e. of referring expressions, is used to refer to it (Vonk, Hustinx \& Simons, 1992; Almor, 1996; Kintsch $\&$ Rawson, 2005). That is why grammatical or zero anaphora are preferred when the discourse topic is maintained or when the antecedent of an expression can be unambiguously identified (Garrod \& Sandford, 1994, 1999). The identification of referents when referential mechanisms are used is also driven by the interlocutors' aim to search for the most plausible interpretation. To that purpose, they resort to frames and scripts that provide a suitable interpretive context (Kintsch \& Rawson, 2005). In (6)

(6) There was a leak in the kitchen, so Sam called the plumber. After only ten minutes, he had already changed the pipe.

The personal pronoun "he" in the second utterance is informatively saturated by linking it to the plumber, and not to Sam, since extralinguistic knowledge tells us that it is plumbers who are in charge of changing a pipe when engaged to do so, and not their clients.

Also in relation to discourse production, cognitive considerations help explain interlocutors' by-default preferences to opt for pronouns amongst the referential mechanisms available in a given language: the informative content of pronouns is comparatively low and, as a result, it is relatively effortless to saturate them. This tenet also finds experimental support a contrario sensu: as the informative salience of the referent decreases, the probability to use lexical anaphors instead of personal pronouns seems to increase. Interlocutors seem to be ready to commit to higher processing efforts in exchange for stronger cognitive effects (Almor, 2000).

As concerns encapsulation phenomena, besides theoretical proposals, their use has been investigated in corpus studies. Corpus-based observation represents a first step towards systematizing production patterns that explain tendencies in the speakers' preferences for the use a specific encapsulation mechanism, and helps establish 
potential conceptual limits for the categorization and distinction of these mechanisms from referring expressions (González Ruiz \& Izquierdo Alegría, 2020).

Corpus studies have demonstrated, for instance, that the use of encapsulators in a thematic or rhematic position can be due to a myriad of factors:

- The discourse genre -and, related to that, discourse modality (idem, cf. also López Samaniego, 2018);

- The informative load of the encapsulation device, understood as the amount of new information it contains (López Samaniego, 2018; González Ruiz \& Izquierdo Alegría, 2020);

- The semantic relation at issue (Parodi \& Burdiles, 2016, 2019) in disciplinary written discourse, which may be associated to preferences for a specific grammatical encapsulator (e.g. ello occurs more often in causality and counterargumentation, and less in additive and temporal relations; eso is more frequent than other grammatical forms (esto, ello) in adversative relations).

- From a pragma-discursive perspective, the strongest implicit persuasive potential of the (evaluative) encapsulator in a thematic position (González Ruiz \& Izquierdo Alegría, 2020), as compared to its occurrence as part of the utterance rheme.

These factors are often intertwined, which makes it difficult to formulate conspicuous predictions for the occurrence of encapsulation mechanisms in communication, in contrast with the systematic findings available for referring expressions, which have enabled clear predictions on discourse production. Indeed, only a few investigations have addressed the effect of encapsulation mechanisms for the construction of discourses experimentally. Recent research deals with the role of neuter encapsulators like Spanish ello ('that') in connective expressions like por ello ('that is why') and a pesar de ello ('despite this'). These expressions exhibit a binary nature, since they have features of referential coherence (the neuter pronoun ello) as well as of relational coherence as argumentative connectives (Parodi, Julio, Nadal, Burdiles \& Cruz Rubio, 2018, 2019; Guillén Jiménez, 2021). In causal relations, results demonstrate a direct relationship between extension of the referents and their distance to the relational device, and utterance processing effort. For counter-argumentative relations marked with a pesar de ello results are still inconclusive. Some studies have found an increased processing effort for longer referent extensions (one vs. two discourse segments, Parodi et al., 2019), while others do not (Guillén Jiménez, 2021).

\subsection{Relational coherence and discourse processing}

Constructing a relevant interpretation also involves recovering 'relational discourse coherence'. To establish relational coherence, interlocutors integrate the mental representations derived from the segments of the discourse utterances and combine 
them with the accessible context ${ }^{3}$ (Sperber \& Wilson, 1995[1986]; Givón, 2005; Sanders \& Spooren, 2007; Pons Bordería, 2008, see also paragraph 1 above). In this frame, coherence is a feature of the mental representation derived 'from' the text, and thus cognitive in nature (Sanders \& Spooren, 2001). Coherence relations model how propositions of a text are integrated into 'a larger whole' (Knott \& Sanders, 1998). Pivotal for the establishment of relational coherence is 'discourse marking'.

As a complement to longstanding and extensive theoretical descriptions of discourse marking available in different languages, experimental endeavors have concentrated on analyzing the effects of discourse markers in utterance processing an interpretation. Discourse markers guide inferential processes by acting as semantic constraints on the relevance of utterances (Portolés, 2001[1998]; Blakemore, 2002; Loureda \& Acín, 2010; Portolés, Sainz \& Murillo, 2021). As instructions-encoding lexical expressions, the semantics of discourse markers is procedural (Blakemore, 2002; Portolés et al., 2021): in contrast to the words "winter" or "breeze" in (7), the counter-argumentative connective "however" is not accessible to consciousness and does not give rise to conceptual representations:

(7) It was winter. However, the breeze was still warm.

Instead, "however" guides utterance interpretation by specifying the discursive status of the discourse segments -an argument and a counter-consequence- and by connecting them to inferentially derive a relevant mental representation and its corresponding implicatures, i.e. that a warm breeze in winter is rather extraordinary.

Discourse relations are 'communicative in nature' (López García, 1999) and can also remain implicit (Degand, 1998; Sanders, 2005; Das \& Taboada, 2013; Evers-Vermeul $\&$ Sanders, 2017, among others). Both juxtaposition and semantic explicitness of a discourse marker are fully-fledged procedures available to speakers to convey discourse relations (Nieuwenhuijsen, 2013), since it is the interlocutors' mutually manifest cognitive environment what leads a speaker to use a specific connective to express a given relation, or rather convey the relation implicitly. Thus, against the background of a cognitive cost-benefit interplay (Sperber \& Wilson, 1995[1986], see also Levy \& Jaeger, 2007 for a proposal from the 'uniform information density hypothesis'), if the accessible context (the co-text and stored mental representations) allows to integrate the discourse segments in relevant manner, procedural guides may not be needed. This is the case in (8), where, in the provided context, a causal relation can be recovered by simply resorting to mental assumptions activated by the juxtaposed utterances:

(8) Anne and George started a successful business a couple of years ago. [They run a very nice hotel $]_{\text {cause. }}$ [They have many guests.] $]_{\text {consequence }}$ 
Empirical evidence confirms that it is the mental representations activated by utterances which determines whether a given relation is conveyed implicitly or explicitly (Murray, 1995, 1997; Brehm-Jurish, 2005; Asr \& Demberg, 2012; Das \& Taboada, 2013; Hoek \& Zufferey, 2015; Hoek, Zufferey, Evers-Vermeul \& Sanders, 2017; Nadal \& Recio Fernández, 2019). In cases of explicit discourse marking, the focus of experimentation has lied so far on the argumentative and on the informative discourse level, and to a lesser extent on the organizational and formulative level of discourse (Loureda et al., 2021).

Experimental findings confirm the context-constraining and inference-guiding effects of discourse markers. Specifically, discourse markers function as effortconstraining semantic devices in the interlocutors' way to recover a communicated assumption (Haberlandt, 1982; Sanders \& Noordman, 2000; Filik, Paterson \& Sauermann, 2011; Loureda et al., 2021, among many others). Although explicating a discourse marker in an utterance implies adding further information to it, interlocutors seem to accept this higher load in exchange for stronger contextual effects (FabriciusHansen, 2005; Loureda et al., 2021). An utterance like (9a) is semantically richer due to the presence of the focus operator even, which evokes a set of alternatives to be contrasted with the focus (i.e. that James talks in many other places). However, a number of studies show that the cognitive effort to recover a relevant assumption from utterances like this one is reduced, compared to the corresponding non-marked example in (9b) containing an informative focus:

(9) a. James talks even under the shower.

b. James talks under the shower.

In line with these findings, as concerns effects on processing patterns, experimental evidence has also shown that introducing a discourse marker in an utterance leads to a 'modification' of the processing strategy followed by interlocutors for discourse interpretation: a discourse marker constrains the global effort needed for utterance processing by setting its maximum processing costs at those of the corresponding unmarked utterance (Loureda et al., 2021).

Besides these global effort-constraining effects, as regards the tasks involved in utterance interpretation, a discourse marker also optimizes initial information-recovery operations, thus systematically controlling the need to reanalyze the utterance (Loureda et al., 2021). At a more local level, the interpretative frame established by a discourse marker also seems to facilitate the integration of the subsequent segment into the mental representation already activated: a discourse marker facilitates prediction of the upcoming discourse content by conventionally indicating the discourse relation to be retrieved and reducing utterance under-determinacy (Sanders \& Spooren, 2001; Filik, Paterson \& Liversedge, 2005; Cozijn, Noordman \& Vonk, 2011; Mak \& Sanders, 2013; Canestrelli, Mak \& Sanders, 2013; Köhne-Fuetterer \& Demberg, 2013; Xiang \& 
Kuperberg, 2015; van Silfhout, Evers-Vermeul \& Sanders, 2015; Köhne-Fuetterer, Drenhaus, Delogu \& Demberg, 2021; Loureda et al., 2021). While (10) and (11) may convey the same discourse relation -a causal-consecutive argumentative relation-, both utterances differ as to the way how interlocutors are guided towards assumption reconstruction:

(10) They run a very nice hotel. They have many guests.

(11) They run a very nice hotel. Therefore, they have many guests.

Discourse markers, in sum, behave as processing-optimizing guides, and they do so for all tasks involved in utterance interpretation: the construction of an initial assumption and its reanalysis; as well as globally, as concerns the total effort needed to recover a communicated assumption.

Systematical experimental findings on this cognitive impact of discourse markers onto discourse processing available for different paradigms and languages (Loureda, Recio Fernández, Cruz Rubio \& Rudka, in print) has led to the formulation of a series of Cognitive Principles of Discourse Marking (Loureda et al., 2021). The Cognitive Principles of Discourse Marking and their corollaries predict effort-constraining effects of discourse markers on the effort needed for utterance interpretation, while at the same time systematically excluding other effects. Also in line with previous findings, the principles validate certain semantic, morphological and distributional properties of discourse markers, and confirm their procedural nature. Furthermore, the predictions established by the principles provide the researcher with a framework of cognitive effects that contributes to discriminating between semantic expressions acting as discourse markers from other expressions functioning at different levels of the construction of discourse (cf. Loureda et al., 2021). In a nutshell, also linking with experimental findings previously available and hypotheses formulated on their basis, the Cognitive Principles of Discourses Marking provide the researcher with a basic frame to further deepen on the study of the construction and reconstruction of discourses as cognitive vehicles for communication.

These findings, finally, can be summarized in four theoretical considerations that reflect the basic link between communication, cognition and discourse marking ${ }^{4}$ :

- Communicative exchanges are built on the basis of decoding and inferential processes.

- During communication, the human mind continuously tests inferential hypothesis online by confronting them with the accessible context, which explains cases of success and failure of communication. 
- Accessing the most relevant context is facilitated by discourse marking, the function shared by all discourse markers, consisting in the conventionalization of instructions guiding inferential processes.

- Since discourse markers regulate the access to the most relevant context for utterance interpretation, they can be presumed an extraordinary communicative value.

\section{CONCLUSIONS AND PERSPECTIVES}

Recovering a relevant mental assumption implies for the interlocutors to connect linguistic input with a mutually manifest cognitive environment. To that purpose, adequate context selection is needed, so that utterance interpretation can take place within an optimum frame in terms of cognitive effort and cognitive benefits. Under these framework, it is expectable that discourse processing may particularly be affected by the mechanisms that interlocutors put to use during communicative exchanges. At the level of referential coherence, the linguistic system allows the interlocutor to connect realities within discourses, and to link them to mental representations thus enhancing discourse coherence and thematic progression. At the level of relational coherence or cognitive discourse connectedness, procedural instructions guide inferential processes and lead to efficient utterance interpretation.

As has been shown along this contribution, approaching discourse studies experimentally allows the researcher to better understand the cognitive mechanisms triggered when interlocutors engage in communication. Quantitatively, in terms of effects of linguistic expressions on processing effort; quantitatively, in terms of the patterns and cognitive strategies followed by interlocutors during the construction of discourse. Particularly, experimental findings provide the scientific community with empirical evidence for the formulation, refinement or reconsideration of principles and theories of communication that contribute towards a holistic view of how cognition, languages and interpersonal relations interact in the construction of discourses. In addition to this, investigating the mechanisms of communication experimentally comes along with a strong potential for applied and knowledge transfer endeavors, as are, for instance, communication consultancy, material design for teaching-learning environments, or literacy studies, among many others.

\section{REFERENCES}

Almor, A. (1996). NP anaphora and focus - The informational load bypothesis. Unpublished doctoral dissertation, Brown University, Providence, USA.

Almor, A. (2000). Constraints and mechanisms in theories of anaphor processing. In M. Crocker, M. Pickering \& C. Clifton Jr. (Eds.), Architectures and Mechanisms for Language Processing (pp. 341-354). Cambridge: Cambridge University Press. 
Ariel, M. (2001). Accessibility theory: An overview. In T. Sanders, J. Schilperoord \& W. Spooren (Eds.), Text Representation: Linguistic and Psycholinguistic Aspects (pp. 2987). Amsterdam: John Benjamins.

Asr, F. T. \& Demberg, V. (2012). Implicitness of discourse relations. In Proceedings of COLING 2012 (pp. 2669-2684). Mumbai, India.

Blakemore, D. (2002). Relevance and linguistic meaning. The semantics and pragmatics of discourse markers. Cambridge: Cambridge University Press.

Borreguero, M. (2018). Los encapsuladores anafóricos: Una propuesta de clasificación. Caplletra, 64, 179-203.

Brem-Jurish, E. U. (2005). Connective ties in discourse: Three ERP-Studies on causal, temporal, and concessive ties and their influence on language processing. Unpublished doctoral dissertation, University of Potsdam, Potsdam, Germany.

Cabedo Nebot, A. \& Recio Fernández, I. (2021). El hablar y la lingüística empírica. In Ó. Loureda \& A. Schrott (Eds.), Manual de lingüística del hablar (pp. 823-842). Berlin/Boston: de Gruyter.

Canestrelli, A. R., Mak, W. M. \& Sanders, T. J. M. (2013). Causal connectives in discourse processing: How differences in subjectivity are reflected in eye movements. Language and Cognitive Processes, 28(9), 1394-1413.

Cookal, D., Sturt, P. \& Ferreira, F. (2018). Processing of It and This in written narrative discourse. Discourse Processes, 55(3), 272-289.

Conklin, K., Pellicer-Sánchez, A. \& Carrol, G. (2018). Eye-Tracking: A guide for applied linguistics research. Cambridge: Cambridge University Press.

Conte, M.-E. (1996). Anaphoric encapsulation. Belgian Journal of Linguistics, 10, 1-11.

Cozijn, R., Noordman, L. G. M. \& Vonk, W. (2011). Propositional integration and world-knowledge inference: Processes in understanding Because Sentences. Discourse Processes, 48(7), 475-500.

Cruz Rubio, A. (2020). Processing patterns of focusing. An experimental study on pragmatic scales triggered by the Spanish focus operator incluso. Unpublished doctoral dissertation, Heidelberg University, Heidelberg, Germany.

Cruz Rubio, A. \& Loureda, Ó. (2019). Processing patterns of focusing in Spanish. In Ó. Loureda, I. Recio Fernández, L. Nadal \& A. Cruz Rubio (Eds.), Empirical Studies of the Construction of Discourse (pp. 195-227). Amsterdam/Philadelphia: John Benjamins. Pragmatics \& Beyond New Series.

Cuenca, M. J. (2010). Gramática del texto. Madrid: Arco Libros. 
Das, D. \& Taboada, M. (2013). Explicit and implicit coherence relations: A corpus study. In S. Luo (Ed.), Actes du Congrès de la Association canadienne de linguistique [on line]. Retrieved from: http://homes.chass.utoronto.ca/ claacl/actes2013/Das_and_Taboada-2013.pdf.

Degand, L. (1998). On classifying connectives and coherence relations. In M. Stede, L. Wanner \& E. Hovy (Eds.), Proceedings of the COLING-ACL Workshop on Discourse Relations and Discourse Markers (pp. 29-35). Montreal: University of Montreal.

Dietrich, R. (2002). Psycholinguistik. Eine Einführung. Stuttgart: J.B. Metzler.

Escandell-Vidal, M. V. (2017). Notes for a restrictive theory of procedural meaning. In R. Giora \& M. Haugh (Eds.), Doing Pragmatics Interculturally (pp. 79-96). Berlin/Boston: de Gruyter.

Escandell-Vidal, V., Leonetti, M. \& Ahern, A. (2011). Preliminary material. In V. Escandell-Vidal, M. Leonetti \& A. Ahern (Eds.), Procedural Meaning: Problems and Perspectives (pp. I-XLV). Leiden: Brill.

Fabricius-Hansen, C. (2005). Elusive connectives. A case study on the explicitness dimension of discourse coherence. Linguistics, 43(1), 17-48.

Filik, R., Paterson, K. B. \& Liversedge, S. P. (2005). Parsing with focus particles in context: Eye movements during the processing of relative clause ambiguities. Journal of Memory and Language, 53(4), 473-495.

Filik, R., Paterson, K. B. \& Sauermann, A. (2011). The influence of focus on eye movements during reading. In S. P. Liversedge, I. Gilchrist \& S. Everling (Eds.), The Oxford Handbook of Eye Movements (pp. 925-941). Oxford: Oxford University Press.

Francis, G. (1994). Labelling discourse: An aspect for nominal-group lexical cohesion. In M. Coulthard (Ed.), Advances in written text analysis (pp. 83-101). London/New York: Routledge.

Fukumura, K. \& van Gompel, R. P. (2012). Producing pronouns and definite noun phrases: Do speakers use the addressee's discourse model? Cognitive Science, 36(7), 1289-1311.

Garrod, S. \& Sanford, A. (1999). Incrementality in discourse understanding. In H. van Oostendorp \& S. R. Goldman (Eds.), The Construction of Mental Representations during Reading (pp. 3-27). Mahwah, NJ: Lawrence Erlbaum.

Garrod, S. \& Sanford, A. (1994). Resolving sentences in a discourse context: How discourse representation affects language understanding. In M. A. Gernsbacher (Ed.), Handbook of Psycholinguistics (pp. 675-698). San Diego: Academic Press. 
Gernsbacher, M. A. (1990). Language comprehension as structure-building. Hillsdale, NJ: Lawrence Erlbaum.

Gillioz, C. \& Zufferey, S. (2021). Introduction to experimental linguistics. London: John Wiley $\&$ Sons.

Givón, T. (2005). Context as other minds. Amsterdam: John Benjamins.

González Ruiz, R. \& Izquierdo Alegría, D. (2020). Encapsulación y estructura informativa: Análisis cuantitativo y cualitativo de las variables influyentes en la selección de patrones temático-remáticos en el editorial periodístico. Zeitschrift für romanische Philologie, 136(3), 749-788.

Graesser, A. C., Singer, M. \& Trabasso, T. (1994). Constructing inferences during narrative text comprehension. Psychological Review, 101(3), 371-395.

Guillén Jiménez, D. (2021). Experimental analysis of the processing schemas of counterargumentation and anaphoric substitution signaled by the Spanish connective a pesar de ello. Unplublished doctoral dissertation, Universität Heidelberg, Heidelberg, Germany.

Gundel, J. \& Abbott, B. (2019). The Oxford Handbook of Reference. Oxford: Oxford University Press.

Haberlandt, K. (1982). Reader expectations in text comprehension. In J. F. Le Ny \& W. Kintsch (Eds.), Language and Comprehension (pp. 239-250). Amsterdam: NorthHolland Publishing Company.

Hoek, J. \& Zufferey, S. (2015). Factors influencing the implicitation of discourse relations across languages. In Proceedings of the 11th Joint ACL - ISO Workshop on Interoperable Semantic Annotation, 39-45.

Hoek, J., Evers-Vermeul, J. \& Sanders T. J. M. (2019). Using the cognitive approach to coherence relations for discourse annotation. Dialogue and discourse, 10(2), 1-33.

Hoek, J., Zufferey, S., Evers-Vermeul, J. \& Sanders, T. J. M. (2017). Cognitive complexity and the linguistic marking of coherence relations. A parallel corpus study. Journal of Pragmatics, 121, 113-131.

Johnson-Laird, P. N. (1983). Mental models: Towards a cognitive science of language, inference, and consciousness. Cambridge: Harvard University Press.

Kamalski, J., Sanders, T. J. M. \& Lentz, L. (2008). Coherence marking, prior knowledge, and comprehension of informative and persuasive texts: Sorting things out. Discourse Processes, 45(4-5), 323-345. 
Keating, G. D. \& Jegerski, J. (2015). Experimental designs in sentence processing research: A methodological review and user's guide. Studies in Second Language Acquisition, 37, 1-32.

Kintsch, W. \& Rawson, K. A. (2005). Comprehension. In M. J. Snowling \& C. Hulme (Eds.), Blackwell Handbooks of Developmental Psychology. The Science of Reading (pp. 209-226). Malden: Blackwell Publishing.

Knott, A. \& Sanders, T. (1998). The classification of coherence relations and their linguistic markers: An exploration of two languages. Journal of Pragmatics, 30, 135-175.

Köhne-Fuetterer, J. \& Demberg, V. (2013). The time-course of processing discourse connectives. In M. Knauff, M. Pauen, N. Sebanz, \& I. Wachsmuth (Eds.), Proceedings of the 35th Annual Meeting of the Cognitive Science Society (CogSci-13) (pp. 2760-2765). Austin TX: Cognitive Science Society.

Köhne-Fuetterer, J., Drenhaus, H., Delogu, F. \& Demberg, V. (2021). The online processing of causal and concessive discourse connectives. Linguistics, 59(2), 417-448.

König, E. (1991). The meaning of focus particles: A Comparative Perspective. London: Routledge.

Levy, R. \& Jaeger, T. F. (2007). Speakers optimize information density through syntactic reduction. In B. Schlökopf, J. Platt \& T. Hoffmann (Eds.), Advances in Neural Information Processing Systems 19 (pp. 849-856). Cambridge, Ma: MIT Press.

López García, Á. (1999). Relaciones paratácticas e hipotácticas. In I. Bosque \& V. Demonte (Dirs.), Gramática descriptiva de la lengua española (pp. 3507-3548). Madrid: Espasa Calpe.

López Samaniego, A. (2014). Las etiquetas discursivas: Cohesión anafórica y categorización de entidades del discurso. Pamplona: EUNSA.

López Samaniego, A. (2015). Etiquetas discursivas, hiperónimos y encapsuladores: Una propuesta de clasificación de las relaciones de cohesión anafórica. Rilce. Revista de Filología Hispánica, 31(2), 435-462.

López Samaniego, A. (2018). La encapsulación nominal en el discurso académicocientífico oral y escrito: Patrones de aparición. Caplletra, 64, 129-152.

Loureda, Ó. \& Acín, E. (Coords.) (2010). Los estudios sobre marcadores del discurso del español, boy. Madrid: Arco Libros. 
Loureda, Ó., Recio Fernández, I., Cruz Rubio, A. \& Nadal, L. (2019). Introduction. In Ó. Loureda, I. Recio Fernández, L. Nadal \& A. Cruz Rubio (Eds.), Empirical Studies of the Construction of Discourse (pp. 1-13). Amsterdam: John Benjamins. Pragmatics \& Beyond New Series.

Loureda, Ó., Cruz Rubio, A., Recio Fernández, I. \& Rudka M. (2021). Comunicación, particulas discursivas y pragmática experimental. Madrid: Arco Libros.

Loureda, Ó., Recio Fernández, I., Cruz Rubio, A. \& Rudka M. (in print). Principles of Discourse Marking: An Experimental Approach of General and Contrastive Perspectives. In L. Degand \& M. J. Cuenca (Eds.), Discourse Markers in Interaction, Berlin/Boston: de Gruyter.

Mak, W. M. \& Sanders, T. J. M. (2013). The role of causality in discourse processing: Effects of expectation and coherence relations. Language and Cognitive Processes, 28(9), 1414-1437.

Mertins, B. (2016). The use of experimental methods in linguistic research: Advantages, problems and possible pitfalls. In T. Anstatt, A. Gattnar \& C. Clasmeier (Eds.), Slavic Languages in Psycholinguistics. Chances and Challenges for Experimental Research (pp. 15-33). Tübingen: Francke.

Moeschler, J. (1989). Modélisation du dialogue. Répresentation de l’inférence argumentative. Paris: Hermes.

Moncada, F. (2018). Interaction between connectives and previous knowledge in the processing of causal coherence. Círculo de Lingüistica Aplicada a la Comunicación, 76, 179-196.

Murray, J. D. (1995). Logical connectives and local coherence. In R. Lorch \& E. O'Brien (Eds.), Sources of Cobesion in Text Comprehension (pp. 107-125). Hillsdale, NJ: Lawrence Erlbaum.

Murray, J. D. (1997). Connectives and narrative text: The role of continuity. Memory \& Cognition, 25(2), 227-236.

Nadal, L. \& Recio Fernández, I. (2019). Processing implicit and explicit causality in Spanish. In Ó. Loureda, I. Recio Fernández, L. Nadal \& A. Cruz (Eds.), Empirical Studies of the Construction of Discourse (pp. 253-270). Amsterdam: John Benjamins.

Nieuwenhuijsen, D. (2013). Yuxtaposición y tradiciones discursivas en el español antiguo. La Corónica, 41(2), 135-172. 
Noveck, I. (Ed.) (2018). Experimentalpragmatics: The making of a cognitive science. Cambridge: Cambridge University Press.

Noveck, I. \& Sperber, D. (2007). The why and how of experimental pragmatics: The case of 'Scalar Inferences'. In N. Roberts (Ed.), Advances in Pragmatics (pp. 184212). Basingstoke, Hampshire: Palgrave Mcmillan.

Ozuru, Y., Dempsey, K. \& McNamara, D. S. (2009). Prior knowledge, reading skill, and text cohesion in the comprehension of science texts. Learning and Instruction, 19(3), 228-242.

Parodi, G. \& Burdiles, G. (2016). Encapsulación y tipos de coherencia referencial y relacional: El pronombre ello como mecanismo encapsulador en el discurso escrito de la economía. Onomázein, 33, 107-129.

Parodi, G. \& Burdiles, G. (2019). Los pronombres neutros esto, eso y aquello como mecanismos encapsuladores en el discurso de la economía. Spanish in Context, $16,104-127$.

Parodi, G., Julio, C., Nadal, L., Burdiles, G. \& Cruz Rubio, A. (2018). Always look back: Eye movements as a reflection of anaphoric encapsulation in Spanish while reading the neuter pronoun Ello. Journal of Pragmatics, 132, 47-58.

Parodi, G., Julio, C., Nadal, L., Burdiles, G. \& Cruz Rubio A. (2019). Stepping back to look ahead: Neuter Encapsulation and Referent Extension in CounterArgumentative and Causal Relations in Spanish. Language and Cognition, 11, 431454.

Pons Bordería, S. (2008). Do discourse markers exist? On the treatment of discourse markers in relevance theory. Journal of Pragmatics, 40, 1411-1434.

Portolés, J. (2001) [1998]. Marcadores del discurso. Barcelona: Ariel.

Portolés, J., Sainz, M. E. \& Murillo, S. (2021). Partículas discursivas e instrucciones de procesamiento. In M. V. Escandell Vidal, J. Amenós Pons \& A. K. Ahern (Eds.), La pragmática (pp. 284-302). Madrid: AKAL.

Quezada, C. (2007). Potencia estadística, sensibilidad y tamaño de efecto: ¿Un nuevo canon para la investigación? Onomázein, 16(2), 159-170.

Rayner, K. (2009). Eye movements and attention in reading, scene perception, and visual search. The Quarterly Journal of Experimental Psychology, 62(8), 1457-1506.

Ribera, J. E., Marín, M. J. \& Alturo, N. (2018). Els mecanismes de referència en la interfície gramàtica-discurs. Cohesió, coherència i cognició. Quaderns de Filologia: Estudis Lingüistics, XXIII, 9-31. 
Rooth, M. (1985). Association with focus. Unpublished doctoral dissertation, University of Massachusetts, Massachusetts.

Rooth, M. (1996). Focus. In S. Lappin \& C. Fox (Eds.), The Handbook of Contemporary Semantic Theory (pp. 271-297). Oxford: Blackwell.

Sanders, T. J. M. (2005). Coherence, causality and cognitive complexity in discourse. In M. Aurnague, M. Bras, A. Le Draoulec \& L. Vieu (Eds.), Proceedings/ Actes SEM05, First International Symposium on the exploration and modelling of meaning (pp. 105114). Toulouse: University of Toulouse - Le Mirail.

Sanders, T. J. M. \& Noordman, L. G. M. (2000). The role of coherence relations and their linguistic markers in text processing. Discourse Processes, 29(1), 37-60.

Sanders, T. J. M. \& Spooren, W. (2001). Text representation as an interface between language and its users. In T. J. M. Sanders, J. Schilperoord \& W. Spooren (Eds.), Text Representation: Linguistic and Psycholinguistic Aspects (pp. 1-25). Amsterdam/Philadelphia: John Benjamins.

Sanders, T. J. M. \& Gernsbacher, M. A. (2004). Accessibility in text and discourse processing. Special issue of discourse processes. Discourse Processes, 37(2), 79-89.

Sanders, T. J. M. \& Spooren, W. (2007). Discourse and text structure. In D. Geeraerts \& H. Cuykens (Eds.), Handbook of Cognitive Linguistics (pp. 916-943). Oxford: Oxford University Press.

Sanders, T. J. M. \& Evers-Vermeul, J. (2019). Subjectivity and causality in discourse and cognition. Evidence from corpus analyses, acquisition and processing. In Ó. Loureda, I. Recio Fernández, L. Nadal \& A. Cruz Rubio (Eds.), Empirical Studies of the Construction of Discourse (pp. 273-298). Amsterdam: John Benjamins.

Sandra, D. (2009). Experimentation. In D. Sandra, J.-O. Östman \& J. Verschueren (Eds.), Cognition and Pragmatics (pp. 157-199). Amsterdam: John Benjamins.

Schmolz, H. (2015). Anaphora resolution and text retrieval: A linguistic analysis of bypertexts. Berlin/Munich: de Gruyter.

Sinclair, J. (1993). Written discourse structure. In J. Sinclair, M. Hoey \& G. Fox (Eds.), Techniques of Description: Spoken and Written Discourse (pp. 6-31). London: Routledge.

Sperber, D. \& Wilson, D. (1995) [1986]. Relevance. Communication and cognition. Second Edition. Oxford: Blackwell.

Sperber, D. \& Wilson, D. (2002). Pragmatics, modularity and mind-reading. Mind \& Language, 17(1-2), 3-23. 
Thagard, P. (2005) [1998]. Mind: Introduction to cognitive science. Second Edition. Cambridge/London: MIT Press.

van Dijk, T. A. (2011). Sociedad y discurso (translated by E. Ghio). Literatura y Lingüistica, 28, 287-292.

van Dijk, T. A. \& Kintsch, W. (1983). Strategies of discourse comprehension. New York: Academic Press.

van Silfhout, G., Evers-Vermeul, J. \& Sanders, T. J. M. (2015). Connectives as processing signals: How students benefit in processing narrative and expository texts. Discourse Processes, 52(1), 47-76.

Vonk, W., Hustinx, L. \& Simons, W. (1992). The use of referential expressions in Structuring discourse. Language and Cognitive Processes, 7(3-4), 301-333.

Wilson, D. (2003). New directions for research on pragmatics and modularity. UCL Working Papers in Linguistics, 15, 105-127.

Winter, B. \& Grice, M. (2021). Independence and generalizability in linguistics. Linguistics [on line]. Retrieved from: https://doi.org/10.1515/ling-2019-0049.

Zufferey, S. (2020). Introduction to corpus linguistics. London: John Wiley \& Sons.

Zunino, G. M. (2014). Procesamiento psicolingüistico de relaciones semánticas: Causalidad y contracausalidad. Unpublished doctoral dissertation, Universidad de Buenos Aires, Buenos Aires, Argentina.

Zunino, G. M. (2017). Procesamiento de causalidad y contracausalidad: Interacciones entre estructura sintáctica y conocimiento del mundo en la comprensión de relaciones semánticas. Revista Signos. Estudios de Lingüística, 50(95), 472-491.

Xiang, M. \& Kuperberg, G. R. (2015). Reversing expectations during discourse comprehension. Language, Cognition and Neuroscience, 30(6), 648-672.

\section{NOTES}

${ }^{1}$ A central thesis in cognitive science sustains that the human mind functions on the basis of representations that combine schemata and computational processes acting upon them (Thagard, 2005[1998]). During communication, such representations require mental abilities to perform inferences upon them and to enrich them contextually. Thus, human interaction deploys as a process combining decoding and inferencing: utterances are minimal ostensive stimuli that trigger cognitive processes in the interlocutor's mind oriented to recovering a 
relevant assumption from the utterance (Sperber \& Wilson, 1995[1986], 2002; Wilson, 2003, see also Johnson-Laird, 1983).

${ }^{2}$ Statistical power is 'the probability of correctly rejecting the null hypothesis' in a statistical test (Quezada, 2007; Winter \& Grice, 2021).

${ }^{3}$ In a theory of mental models (van Dijk \& Kintsch, 1983; van Dijk, 2011), the context is not an immanent or objective construct, external to interlocutors. Rather, it is influenced by sociocultural, socio-cognitive and political factors, which enter the interpretive process leading to mental models, which are subjective. Such external influences coincide with the concept of context in relevance theory, which is dynamic: it comprises information obtained from previous utterances or the environment and any assumption entertained in short or long-term memory; and it is not given a priori, but chosen during utterance interpretation (Sperber \& Wilson, 1995[1986]; Moeschler, 1989).

4 These effects describe an optimal interaction between the procedural meaning of a discourse marker and the text, in the sense that they reflect communicative exchanges in which previously mind-stored assumptions (= world-knowledge) confirm or at least do not enter into conflict with the rigid instruction of the discourse marker (Escandell-Vidal et al., 2011, Escandell-Vidal, 2017). There are, however, cases of conflict between the rigidity of procedural meanings and the mental representations derived from an utterance. For instance, in Anna speaks Chinese, French and even English, the contextual constraints imposed by the focus operator even clash with mind-stored assumptions of, for example, a Spanish-speaking person, for whom knowing Chinese is usually less expectable than English or French (cf. Cruz Rubio, 2020, Loureda et al., 2021). This mismatch between the accessible context imposed by the rigid instruction of the discourse marker and previously stored assumptions triggers a need for readjustment by the interlocutor to repair the conflict and recover a relevant assumption. Two possibilities then open up: either abandoning processing, or initiating a process of accommodation (Loureda et al., 2021, 186-194). Accommodation is effortful because it implies adding new communicative material to the context (Escandell-Vidal et al., 2011), but at the same time it does not exclude contextual effects. Experimental evidence dealing with these processes for discourse markers belonging to different functional paradigms has led to the formulation of the Fifth Principle of Discourse Marking, according to the described conflicts systematically lead to differentiated processing compared with non-conflictive (Loureda et al., 2020, 2021). A substantial deal of research has also dealt with the interaction of world-knowledge and the presence or absence of processing instructions, as encoded in discourse markers, for discourse processing and comprehension. Most findings point to an inverse relation of the degree of world-knowledge or expertise in a given topic and the effort-constraining and comprehension-enhancing effect of discourse markers, with non-experts benefiting more from the explication of a discourse marker than experts (Zunino, 2014, 2017; van Silfhout et al., 2015; Moncada, 2018; but see Kamalski, Sanders \& Lentz, 2008; Ozuru, Dempsey \& McNamara, 2009). 